\title{
Eva Barreno Rodríguez at 70: the person and the professional
}

\author{
Ana Crespo $^{1} \cdot$ Pradeep K. Divakar $^{1} \cdot$ Lucia Muggia $^{2} \cdot$ Arnoldo Santos $^{3}$ \\ Published online: 22 October 2020 \\ (C) Springer Nature B.V. 2020
}

This introduction is intended for those who do not know Eva Barreno personally, or who know of her only by reputation. We have had the privilege of working, and sharing our time and experiences with Professor Barreno and, above all, have the honour to call her our friend.

\section{Teaching and scientific career}

Eva Barreno Rodríguez is a Spanish scientist, born in Madrid on 5 December 1950, with close connections to Asturias. She has been living in Valencia for the last 35 years and currently holds the Chair of Professor of Botany at the University of Valencia, previously being associate professor at the Complutense University of Madrid (UCM) and assistant professor at the Autonomous University of Madrid (UAM). Teaching is an activity to which she has dedicated herself with success and enthusiasm. She has taught a wide variety of subjects in various programs of Basic Botany, Biogeography, as well as in Environmental Biology. Other more specific topics include Mycology and Biological Symbiosis, to name but a few. The hallmark of her teaching, as her students are all keen to point out, is the great effort she invests in doing fieldwork, an activity she relishes. Her popularity as a teacher is evident from the remarkable number of students (16 to date) who have sought to do their $\mathrm{PhD}$ with her, indeed, there is a long list of 29 undergraduate students whose Bachelor theses or monographic works she has supervised. Her teaching has always been compelling because of the conviction she transmits about the knowledge she herself has

Lucia Muggia

lmuggia@units.it; lucia_muggia@hotmail.com

1 Departamento de Farmacología Farmacognosia y Botánica Facultad de Farmacia , Universidad Complutense de Madrid Plaza de Ramón y Cajal , 28040 Madrid, Spain

2 Department of Life Sciences, University of Trieste, via L. Giorgieri 10, 34127 Trieste, Italy

3 Calle Guaidil 16, 38280 Tegueste, Tenerife, Spain acquired and her belief in the value of continuing to learn throughout life.

Another important aspect of Eva Barreno's professional work is her organizational skill. She has secured funding for projects of excellence from competitively awarded public sources (19 national and regional projects) which ran for several years, as well as 10 international or co-financed projects. In addition, she obtained grants from public and private sources that have enabled her to lead 17 development and transfer projects arising from her research. All these achievements, and others not detailed here, are proof of her impressive leadership abilities and her great willingness to mobilize staff and material resources in the institutions in which she has worked.

To measure the impact of a researcher's scientific contribution to humanity's stock of knowledge requires a detailed analysis of his/her achievements, and time for the scientific community to appraise. It is not our intention to present a historical analysis of Eva Barreno's work here. International bibliometric analyses are not an entirely robust means of assessment, but they are nevertheless useful for gauging a researcher's impact on their scientific field and beyond. In the case of Eva Barreno, evidence provided by her curriculum vitae is impressive. She is the author of around 250 articles, most of them published in internationally renowned journals, and about 50 of them in journals such as, Plant Science, or those in other areas with equivalent status, in other words in the top quartile by citation frequency. In the field of lichenology, Eva Barreno's publications have a citation rate that corresponds to an $\mathrm{H}$ index of 25 or 35 (depending on the breadth of the databases considered), which puts her among the top researchers in the international lichen community.

\section{Scientific interests and achievements}

As a researcher, Eva Barreno has tackled a range of purely basic research problems in Ecophysiology, Symbiosis and Taxonomy. On the other hand, she has quite often undertaken applied projects of practical value. The most characteristic aspect of her scientific profile is her consistent striving to go 
the extra mile in any project to which she has committed. Where other researchers might settle for continuing to make progress along their tried-and-tested paths, Eva Barreno has not been content to do so being particularly drawn to conceptual and methodological innovation.

Eva Barreno's recent projects have kept her and her group at the cutting-edge of research in lichenology. With fruitful collaboration of colleagues from related disciplines, she has continued to delve into questions of great interest, developing new approaches to understanding lichen symbiosis. More than a decade ago, Eva was able to confirm her hypothesis about the diversity of photobiont species within the lichen thallus. As part of this line of research, she and her collaborators made notable advances, such as the discovery that the thalli of Ramalina farinacea can host up to 27 species of microalgae, of which the Trebouxia sp. TR9 and Trebouxia jamesii species are the predominant. The research team also established that these two algal species have different tolerance limits to particular environmental changes. Eva and her team had other notable achievements of general interest, such as determining the genome sequence of Trebouxia sp. TR9. Another exciting highlight was to find firm evidence for the horizontal transfer of introns between plastids of lichenized algae, fungi and bacterial co-symbionts. The findings concerning the function of the metabolic machinery operating in Trebouxia sp. were also promising. Of particular note was evidence gathered about the metabolic effects on the algae of prolonged in vitro exposure to high salt concentrations. These breakthrough results are fascinating, as they suggest that symbiotic microalga may have developed efficient alternative molecular pathways to cope with saline environments. It is noteworthy that this research group has published a score of pioneering papers that provide a map of progress in a field that requires more study and is of continuing relevance. Eva Barreno has achieved more than can be mentioned here in the limited available space, but the complete list of her publications can be accessed via databases such as:

https://scholar.google.com.mx/citations?user= CAfMiwsAAAAJ\&hl=es\&oi=ao.

\section{Biography}

Eva Barreno benefited from an enviable education thanks to her family, especially her dear parents who have always been so important to her. Eva's family instilled in her the virtue of effort, the love of work, the value of loyalty in one's actions and of generosity towards other people. Eva and her sister, Marisa, are the fruits of that environment, and these values characterize her close, enduring family relationships. With these attributes and her iron will, Eva has dedicated her life to the scientific and teaching profession, for which there can never been enough hours in the day. Indeed, for many years, work and leisure were inseparable for her. This attitude, instilled, many years before, was crucial to her making some of the biggest decisions in her life.

In 1972, as a brilliant Biological Sciences student at the UCM, she approached Salvador Rivas-Martínez, attracted by the possibilities of doing geobotanical and phytosociological research in his group. At that time, Salvador Rivas-Martínez's team, in the Faculty of Biology, included Ana Crespo and our colleagues Jesús Izco, Manuel Costa, José Luis Pérez-Cirera and Carlos Arnáiz. Eva Barreno impressed her colleagues not only by her intellectual strengths and capacity for hard work, but also by her active, passionate and friendly spirit, her warmth and her generosity with her time. She collaborated with everyone from the outset and established professional relationships that would last long into the future, while also establishing deep bonds of friendship, just as she did a few years later when Leopoldo Sancho joined the fledgling lichenology group.

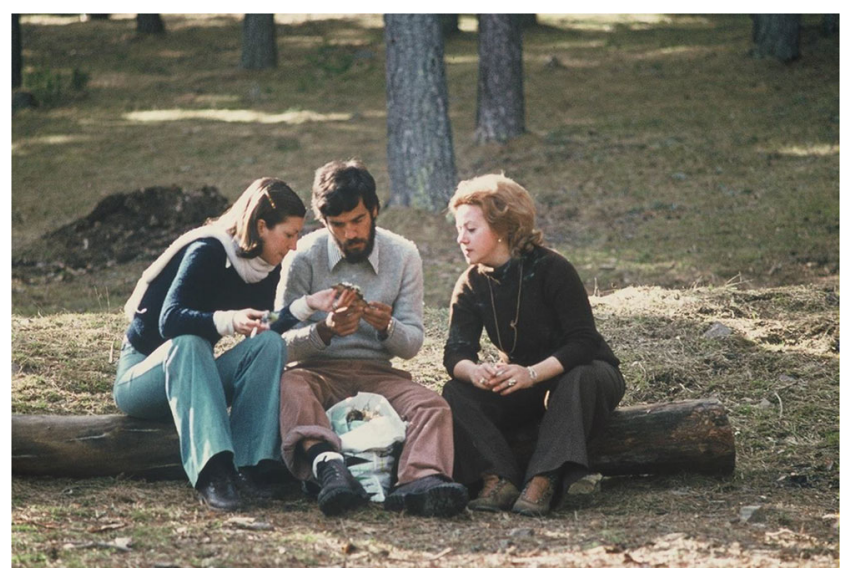

Eva Barreno (right) with Arnoldo Santos (center) and Ana Crespo (left) (Navacerrada, Spain, 1975).

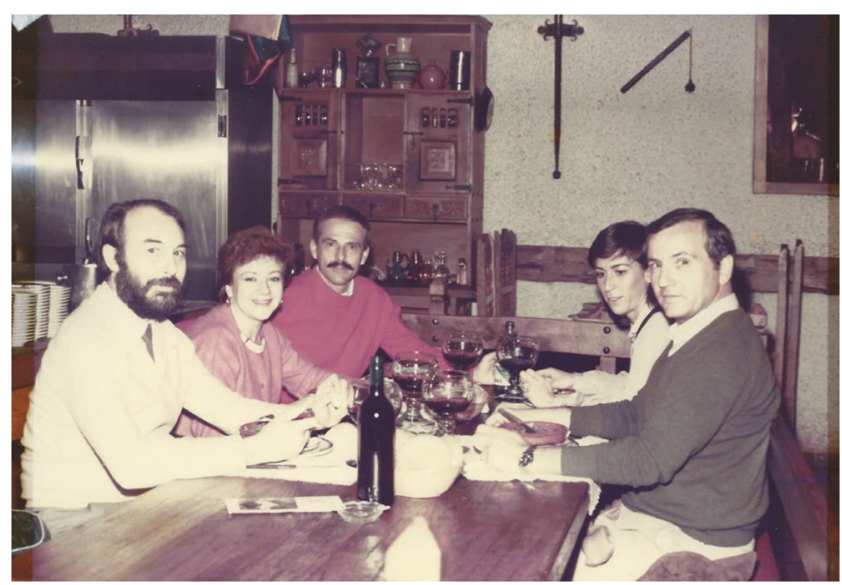

Tomando unas tapas y unos vinos ('Having some snacks and some wine'). From left: Jesús Izco, Eva Barreno, Salvador Rivas Martínez, Ana Crespo and Manuel Costa (Madrid, Spain, 1976).

In 1975, Eva Barreno met Arnoldo Santos, a young botanist from the Canaries who took up a postdoctoral fellowship in the Department with Salvador Rivas-Martínez. They 
greatly influenced each other as professionals and as friends, and their relationship was the source of several basic scientific outputs. This prompted knowledge transfer in ecological projects on vegetation and biodetection, especially in the Canary Islands, where the work continues to this day. This influence was the source of her developing expertise in the biogeography of the Canary Islands and of her vast knowledge of the Macaronesian Region.

Eva first ventured into the world of lichens with Ana Crespo, and soon after, with Xavier Llimona from Barcelona. The three of them significantly broadened the scope of lichenology in Spain. Eva's first positions, at the UCM, were in the Faculties of Biology (1973-1977) and Pharmacy (from 1977). Her flair for leadership was first evident when she recruited a new group of students that she had inspired during her short but productive time as a Professor at the UAM (1983-1985). Among this group of young people was Víctor Jiménez Rico, her first doctoral student. He became a close collaborator and, to this day, a friend. Another of her outstanding, early companions and close friends is Víctor M. Vázquez, who now works at the University of Oviedo (Asturias), but who trained in Eva's group in Madrid.

In 1986, Eva Barreno took up the Chair of Botany at the University of Valencia, a move that proved to be an important one. Her world expanded and she rapidly garnered prestige in the University, not only as a researcher, but also as a teacher and postgraduate supervisor. In her career, in Valencia, she has supervised the theses of $16 \mathrm{PhD}$ students, several of whom have gone on to become University Professors or researchers at the CSIC and in other research centres. Students, postdoctoral fellows and colleagues, especially from her years in Valencia feature frequently in Eva's conversations today, prompting affectionate memories. These include Simón Fos, Vicent Calatayud, and Ángeles Calatayud, and shortly threafter, Sergio Pérez Ortega and Francisco Gasulla, and, more recently, Salvador Chiva, Andreu Manzanera and Cristina Dumitru, and especially Arantxa Molins and Patricia Moya.

Another strikingly broad and constant theme in Eva Barreno's professional life is her strong commitment to organizing specialized courses and scientific meetings, a role she has considered important since 1975. Apart from the notable and frustrating exception of the II Symposium on Cryptogamy (described in the anecdote below), her balance sheet is unfailingly positive and her impact has been widespread, nationally and internationally. The success of Eva's scientific managerial activity largely relies on her tremendous capacity for work and organization. She has an unswerving ability to judge the opportunity for scientific subjects across a broad thematic spectrum involving many disciplines. An example of particular relevance is her sponsorship of the appointment of Lynn Margulis as Doctor Honoris Causa of the University of Valencia, an award that was bestowed in 2001.

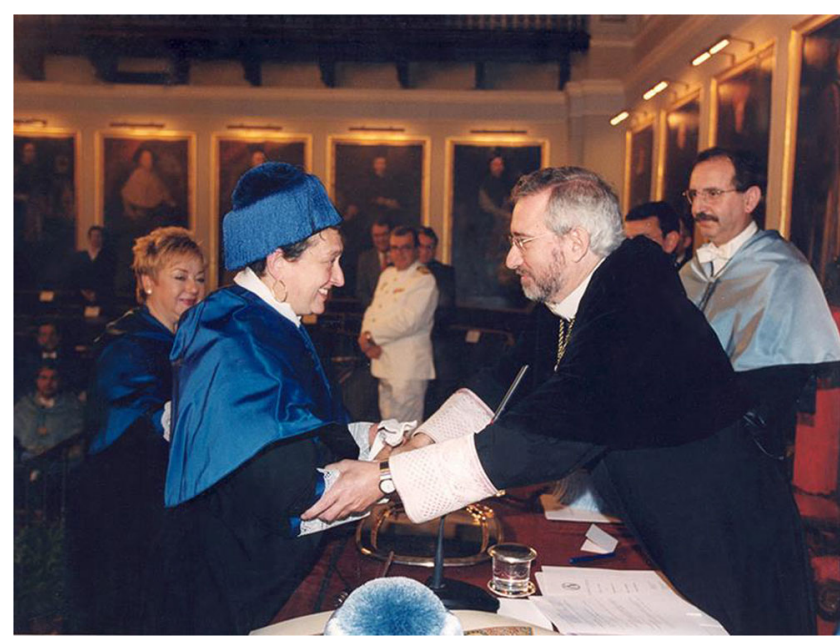

Ceremony to bestow the degree of Doctor Honoris Causa on Lynn Margulis, of which Eva Barreno (left) was the sponsor (University of Valencia, Spain, 8 June 2001)

Eva Barreno's botanical collecting trips really deserve a chapter of their own. She organized and led these throughout Spain, and in many regions of the world as part of the work on her own projects, with the Spanish administration, or within the framework of highly diverse international programs. In many cases, she undertook these collecting campaigns during stays as a visiting researcher in many international research centres. In particular, a highlight was the many visits she made from 1995 to 2005 to the U.S.A that included the USDA's Forest Fire Laboratory at the Forest Service Pacific Southwest Research Station, Riverside, California. There she worked with Patrick J. Temple and Andrezj Bytnerowicz. In the USA, she also collaborated with Thomas Nash (Arizona State University, USA), and this culminated in her participation in the important Sonoran Desert flora project that he led.

\section{Origins and anecdotes: biological soil crust lichens and November 1975}

Eva Barreno first trained as a systematic biologist, identifying and observing morphological characteristics, variability and diversity, mainly of lichens. She would classify each plant and lichen with the excitement of someone making a new discovery. She was most strongly attracted to lichens, possibly because of the difficult challenge they presented. The flora of Harmand (Jean Armand (Abbé), Lichens de France, Catalogue Systématique et Descriptif, Epinal, France, 1905-1913) and the newly released Clauzenda (Ozenda P. \& Clauzade G., Masson, Les Lichens, 1970) were her initial works of reference.

When she began her scientific work, the Spanish scientific community was not well connected to the outside world, but from the outset, Eva associated with renowned specialists from other European countries. Her early visits to Hannes Hertel, of 
the Botanische Staatssammlung München (Munich, Germany), were important because she not only acquired knowledge and a methodology for her work that enabled the two of them to confirm the identity of many difficult groups, such as the lecidioid lichens, but also because she learned how to manage collections and to assimilate the rules of taxonomy and nomenclature. After that, she was in close contact with Joseph Poelt (Karl-Franzens-Universität Graz, Austria), and Antonin Vězda of the Academy of Sciences of the Czech Republic (at that time known as the Czechoslovakian Academy of Sciences; Prague, Czech Republic). These and other taxonomists were a major influence on her development as a researcher. During this early period in the 1970s she undertook the work that led to the publication of her pioneering papers on Spanish lichens. The first of these were the description of Buellia follmannii in the sedimentary gypsum rock strata of Madrid (Anal. Inst. Bot. Cavanilles 1975, 32(1): 121-124) and the floristic and ecological research on the lichen vegetation of the sedimentary rocks of central Spain (Anal. Inst. Bot. Cavanilles 1975, 32(2): 873908). Eva Barreno's thesis, which she brilliantly defended in 1975, was a floristic, phytosociological and ecological study of terricolous lichens in the Madrid region. It comprised a wideranging catalogue and offered fascinating observations about these lichen communities, many of which she subsequently worked on. Despite her initial fondness for terricolous and rock-crevice lichens, the yellow Acarospora species of the Iberian quartzite rock faces and screes engaged her for many hours. This involved her in fieldwork and visits to herbaria and to regions where this type of lichen abounds.

\section{Two anecdotes}

It is impossible for some of Eva's old friends not to remember her, during the early stages of her doctorate, searching for terricolous lichens, and crying out enthusiastically whenever she found the species she had been looking for. One of the images that comes readily to mind is of Eva scrutinizing the biological soil crusts of the gypsicolous hills to the south of Madrid, in full sunlight, often on the verge of dehydration, crawling, magnifying glass in hand, with her face a few centimetres from the ground. This was how Eva Barreno's unquenchable enthusiasm for lichens. in all their diversity, was forged. It was in an ecosystem that commands considerable scientific attention to this day. Her first laboratory was filled, day after day, with hundreds of small cardboard boxes of different shapes and provenance. These were stacked around her, as she sat at her bench with her magnifying glass and microscope. These samples were inexorably perishable and often fell to pieces between her fingers or when she cut them with a blade under the magnifying glass. However, Eva almost never became upset by this, and time and time again, in constant good humour, she would return to the field to collect more of the material she needed.

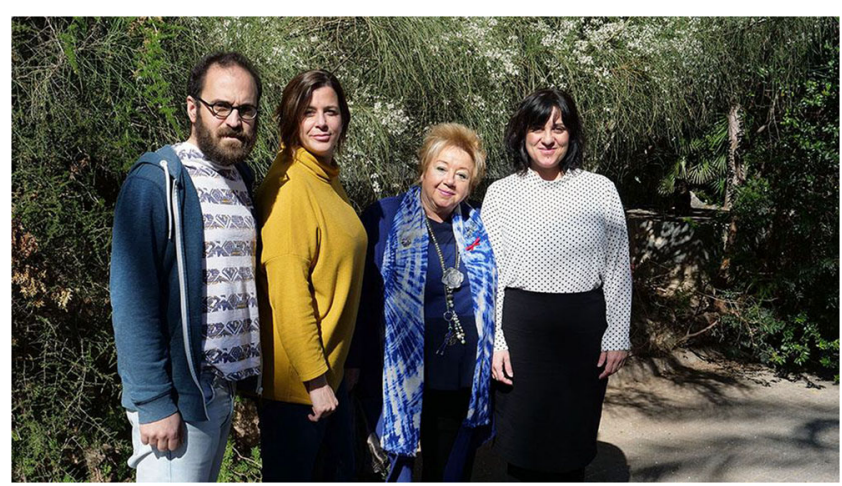

Eva and her closest research collaborators, from left to right: Salvador Chiva, Arantxa Molins, Eva Barreno and Patricia Moya (Valencia, Spain, 2019).

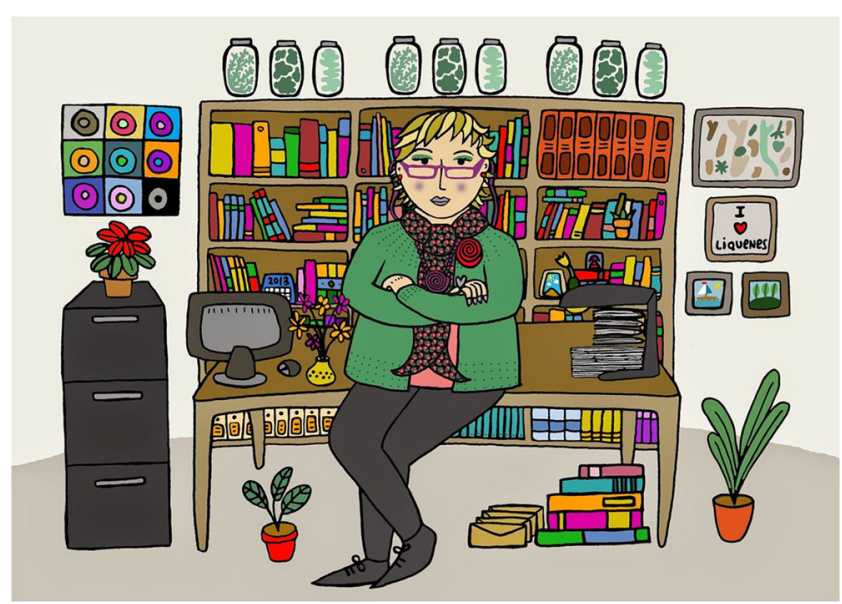

Eva Barreno in her office (portrayed byAraceli Isaac Delso as a present of her research group for her birthday).

The second anecdote is historic in nature, and concerns the first and only notable failure of Eva's fruitful approach to scientific management. The culprit was the undeniably historic character of Francisco Franco. Eva Barreno was part of the organizing committee of the II Symposium on Cryptogamy (Cryptogamic Botany in Spain, Stvdia Botanica 13: 15-20, 1994), which was due to take place on 20 November 1975. On that day, the organizers had everything prepared for the opening of the Symposium in the Faculty of Biology of the UCM. However, after 35 years of dictatorship, Franco died that morning, just before 5 a.m. His death was not unexpected because he was 82 year old and had been in hospital for a month. However, nobody could quite believe it and, above all, no Spaniard could be indifferent to the news. Many of the Symposium attendees turned up at the University although they knew the event would be cancelled by order of the government. They were nevertheless eager to see their colleagues and friends. The organizing committee had to decide what to do about the invited speakers. Salvador Rivas-Martínez, the chair 
of the committee and director of the research group to which Eva Barreno belonged, was particularly concerned about the immediate and unpredictable political consequences. This was especially because he understood the mood of his young collaborators and so he decided to keep them all together. Following the announcement that the President of the Government would shortly address the nation, the group listened to the broadcast. Salvador Rivas-Martínez locked himself and everyone else in his office, with most people having to sit on the floor, as he turned on the radio. Great emotion filled the air, a circumstance that is difficult to describe. Some people cried, though not out of pity and it was decided that it would be wise to leave Madrid. As a result, impromptu fieldtrips were quickly organized. Eva Barreno, Ana Crespo, Arnoldo Santos, and Gerhard Follmann (Naturkundemuseum im Ottoneum, Kassel, Germany), who was one of the guests at the symposium, made a trip to Extremadura to find Acarosporetum epithallino-hilaris (Sobre las comunidades liquénicas rupícolas de Acarospora hilaris (Duf.) Hue en la Península Ibérica. Anal. Inst. Bot. Cavanilles, 33: 189-205. 1976). It turned out to be a profitable journey on that day in November 1975. However, the II Symposium on Cryptogamy, on which Eva Barreno had worked so hard, was soon forgotten. With this anecdote, we not only pay tribute to Eva, but also acknowledge her great respect for her teacher, Salvador Rivas Martínez, whose recent death she still mourns.

In this biography, the authors hope to have provided a portrait of the professional life of Eva Barreno. More activities lie ahead and we trust that the results of her future studies will be at least as productive as those to date. We have no doubt whatsoever that, in the time to come, she will continue working with energy, passion and success.

Publisher's note Springer Nature remains neutral with regard to jurisdictional claims in published maps and institutional affiliations. 